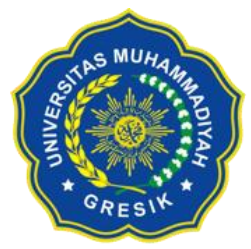

MATRIK

Jurnal Manajemen dan Teknik Industri-Produksi

Journal homepage: http://www.journal.umg.ac.id/index.php/matriks

\title{
Pengukuran Beban Kerja Fisiologis dan Psikologis Kuli Panggul di PT. Pelindo III
}

\section{Wisda Mulyasari}

Program Studi Teknik Industri , Fakultas Teknik, Universitas Muhammadiyah Gresik Jl. Sumatera 101, GKB Gresik, Jawa Timur, Indonesia mulyasari.wisda@gmail.com

\begin{tabular}{l}
\hline INFO ARTIKEL \\
\hline doi: $\mathbf{1 0 . 3 5 0 5 8 7 / M a t r i k}$ \\
$\mathbf{v 1 8 i 2 . 5 8 9}$ \\
\\
\hline Jejak Artikel : \\
Upload artikel \\
16 Januari 2020 \\
Revisi oleh reviewer \\
11 Maret 2020 \\
Publish \\
30 Maret 2020 \\
\hline
\end{tabular}

\author{
Kata Kunci : \\ Beban Kerja, \\ Beban fisologis, \\ Beban psikologis, \\ NASA-TLX, \\ $\% C V L$, \\ Energiekspenditur,
}

ABSTRAK

Pada dasarnya sebuah pekerjaan yang menggunakan fisik secara berlebihan secara terus menerus akan mengakibatkan beban kerja fisiologis dan pekerjaan yang menuntut mental berlebih pasti akan berdampak stress. Bekerjapada kondisi tersebut, apabila dilakukan dalam jangka waktu yang lama dapat berimbuh pada meningkatnya kelelahan yang dialami oleh pekerja sehingga dapat menyebabkan penurunan performa kerja,resiko cedera atau kecelakaan, bahkan terjadinya penyakit akibat kerja. Pekerjaan buruh angkut adalah pekerjaan yang beresiko sehingga perlu dilakukan pengukuran serta evaluasi terhadap beban kerja yang dialami oleh pekerja, baik beban kerja psikologis maupun beban kerja fisiologis. Metode yang digunakan adalah metode kuesioner NASATLX, metode denyut nadi (\%CVL) dan perhitungan energy ekspenditur. Pengukuran dilakukan terhadap 3 koresponden yang berprofesi sebagai buruh angkut di pelabuhan Gresik, PT. Pelindo III. Hasil pengukuran NASA-TLX masuk pada kategori nilai 80-100 yang artimya bahwa beban kerja psikologis ketiga pekerja sangat tinggi. Sedangkan hasil pengukuran beban kerja fisiologis menggunakan \%CVL didapatkan hasil 60-<80 masuk dalam klasifikasi pekerjaan dalam waktu singkat. Sedangkan perhitungan energy ekspenditur ketiga responden diketahui bahwa pekerjaan buruh angkut masuk dalam kategori berat. PT. Pelindo III perlu melakukan upaya perbaikan dalam metode kerja agar dapat menurunkan beban kerja baik itu psikologis dan fisiologis kedalam kategori aman sehingga menurunkan resiko penurunan performa kerja, cedera, kecelakaan, maupun penyakit akibat kerja. 


\section{Pendahuluan}

PT. PELINDO III Gresik adalah sebuah perseroan terbatas pelabuhan Indonesia yang beroperasi sebagai pengelola dan pengembang pelabuhan untuk kebutuhan distribusi logistik atau pelabuhan sebagai pelayan warga terkait logistik via laut. Aktivitas bongkar muat barang pada kapal yang sandar di dermaga PT Pelindo III ini masih menggunakan cara kovensional yaitu bongkar muat menggunakan kuli panggul memindahkan barang dari kapal ke mobil dan pada saat menurunkan barang dari mobil ke lokasi tujuan. Berdasarkan hasil wawancara, pekerja kuli panggul yang bekerja disana adalah pekerja lepas yang dibayar dengan tariff yang murah yaitu mulai dari Rp.12.000/ton

Aktivitas bongkar muat tersebut dilakukan secara terus menerus selama lebih dari 8 jam/hari. Oleh karena itu dalam penelitian ini akan diukur beban fisik/fisiologi dan beban mental/psikologis pekerja kuli panggul tersebut. Pengukuran beban kerja ini sangat penting dilakukan karena pada dasarnya sebuah pekerjaan yang menuntut fisik akan berdampak pada cedera dan kelelahan fisik itu sendiri dan pekerjaan yang menuntut mental yang berlebih pasti akan berdampak stress pada pekerja tersebut jika kondisi dari pekerjaan tersebut dilakukan dalam jangka waktu yang lama [1]. Kelelahan fisik dan mental berimbas pada penurunan performa kerja dan rawan terhadap cedera atau kecelakaan, bahkan dapat beresiko terjadinya penyakit diovascular mobil yang dapat menyebabkan pekerja tersebut pensiun dini [2].

Beban kerja adalah keadaan dimana pekerja dihadapkan pada tugas yang harus . ' saikan pada waktu tertentu [3]. Beban 14 terdiri atas beban kerja fisik dan beban kerja mental yang keduanya tidak dapat dipisahkan ketika seseorang melakukan suatu pekerjaan [4]. Beban kerja fisik adalah beban perkerjaan yang di terima oleh fisik pekerja yangdilakukan dengan mengandalkan kegiatan fisik semata akan mengakibatkan perubahan pada fungsi alat-alat tubuh. Penilaian beban kerja fisik dapat dilakukan dengan dua metode secara objektif, yaitu metode penilaian langsung dengan mengukur energi yang dikeluarkan melalui perhitungan asupan oksigen dan metode tidak langsung dengan mengukur denyut nadi selama bekerja [5].

Beban kerja mental merupakan isu penting dalam area system kerja[4]. Pada prinsipnya timbulnya gangguan mental dan stress dapat terjadi akibat dari beban kerja yang tidak cocok dan sumber daya pekerja mental. Ada beberapa metode umum yang dapat digunakan dalam konsep Subjektif Mental Workload (SMWL) dalam mengukur beban kerja mental, antara lain adalah skala Cooper-Harper, Teknik Penilaian Beban Kerja Subjektif (SWAT), NASA-TLX, dan metode kuesioner [6]. Sedangkan pengukuran beban kerja mental secara objektif bias dilakukan dengan cara pengukuran variabilitas denyut jantung, pengukuran selang waktu kedipan mata, pengukuran kadar asam saliva dan flicker test [7]. Penelitian beban kerja mental dengan NASA-TLX pernah dilakukan di PT. LG Electronics Indonesia yaitu salah satu perusahaan manufaktur yang bergerak dalam bidang elektronika dengan produk yang dihasilkan seperti televisi, kulkas, ac dan sebagainya. Hasil penelitian menyatakan bahwa beban kerja yang yang paling tinggi adalah pada bagian Assembly dengan skor (61), Packaging (60), SMT (58), Quality Control (56) dan Test (54) [8]

Selain penelitian beban kerja mental, ada beberapa penelitian terdahulu juga pernah mengukur beban kerja mental dan juga beban kerja fisik untuk beberapa objek pekerjaan. Namun untuk objek kuli panggul belum pernah dilakukan. Adapun penelitian terdahulu yang pernah dilakukan yaitu pengukuran beban mental dan fisik pada pekerja di industri tekstil dengan menggunakan metode NASA-TLX, denyut nadi dan suhu tubuh [9]. Hasilnya pengukuran beban kerja mental pekerja pada bagian packing tergolong pada kriteria sangat tinggi, namun pengukuran beban kerja fisikpada stasiun kerja yang sama masih pada kriteria ringan. Pengukuran serupa juga pernah 
dilakukan kepada operator produksi teh hijau di PT MITRA KERICI dengan menggunakan metode NASA-TLX dan denyut nadi [10]. Hasil penelitian menunjukkan bahwa beban kerja mental pada aktivitas pemetikan teh dan produksi teh hijau tergolong kategori tinggi yaitu berada pada range 50-79,99. Adapun pengukuran beban kerja fisik berdasarkan metode denyut nadi tergolong kategori beban kerja ringan. Analisis beban kerja fisik dan mental juga pernah dilakukan pada 10 orang karyawan di PT. Energi Agro Nusantara sebuah perusahaan yang memproduksi bioethanol. Metode yang digunakan adalah \% CVL dan NASA-TLX. Hasilnya adalah beban kerja fisik pada tingkat rendah karena berada pada rentang kurang dari $30 \%$ sedangkan tingkat beban kerja mental tinggi karena nilai skor NASA-TLX berada pada rentang 50-79. [5]

Pada penelitian terdahulu metode yang digunakan selalu sama yaitu \% CVL untuk pengukuran beban fisik dan NASA-TLX. Untuk pengukuran beban kerja mental. Metode NASA-TLX ini dipilih karena lebih mudah tetapi lebih sensitif pada pengukuran beban kerja [7]. Namun pada penelitian ini, selain menggunakan metode \% CVL dan NASATLX, peneliti juga ingin menambahkan satu metodelagi yaitu pengukuran Energy expenditure atau besarnya energi yang di keluarkan untuk suatu pekerjaan dengan memperhitungkan denyut jantung dan faktor demografi yaitu umur, tinggi badan dan jenis kelamin. Hal ini dikarenakan untuk pekerjaan kuli angkut jika hanya menggunakan metode \% CVL maka hanya akan diketahui bahwa jenis pekerjaan tersebut merupakan pekerjaan dalam waktu singkat namun belum diketahui klasifikasi pekerjaan tersebut apakah termasuk kategori ringan, sedang, berat, sangat berat atau extreme berat. Sehingga penambahan pengukuran Energy expenditure akan menutupi kekurangan metode \% CVL.

Dengan adanya penelitian ini, diharapkan bisa menjadi bahan informasi yang dapat dipergunakan PT.PELINDO III untuk memperbaiki sistem kerja dan memperbaiki kebijakannya baik dari system upah maupun metode kerja agar dapat menurunkan beban kerja baik itu psikologis dan fisiologis ke dalam kategori aman sehingga menurunkan resiko penurunan performa kerja, cedera, kecelakaan, maupun penyakit akibat kerja terhadap kuli panggul karena keberadaan kuli panggul tersebutmasih diperlukan dalam aktivitas bongkar muat barang di pelabuhan.

\section{Metode Penelitian}

Pengambilan data dilakukan terhadap 3 responden yang bekerja sebagai kuli panggul yang bekerja bongkar muat barang pada kapal yang berada di pelabuhan Gresik yang berada di bawah naungan PT. PELINDO III. Adapun data-data yang dikumpulkan adalah hasil kuisioner NASA-TLX untuk mengukur beban psikologis, data denyut nadi pekerja pada saat bekerja selama 1 menit, denyut nadi pekeja pada saat istirahat selama 1 menit, umur, tinggi badan dan jenis kelamin.

\subsection{NASA-TLX}

Metode NASA- TLX adalah metode yang digunakan untuk mengukur beban kerja mental yang didasarkan pada enam dimensi : Kebutuhan Mental, Kebutuhan Fisik, Kebutuhan Waktu, Performansi, Tinkat Frustasi dan Usaha[5]. Metode ini telah digunakan di beberapa situasi untuk menilai beban kerja operator dalam lingkungan yang kompleks. Pada pekerjaan kuli panggul, pengukuran beban kerja mental ini perlu juga diukur karena selain terdapat Kebutuhan Fisik (KF) seperti menarik, mendorong dan mengangkat barang dengan beban berat, pekerjaan ini juga terdapat Kebutuhan Mental (KM) seperti menghitung dan mengingat jumlah barang yang dibongkar. Pekerjaan ini juga terdapat Kebutuhan Waktu (KW) karena kuli angkut dituntut untuk bekerja secara cepat dan melelahkan sehingga membutuhkan usaha (U) baik dari fisik dan mental untuk menyelesaikan pekerjaan bongkar muat barang tersebut. 
Adapun langkah-langkah pengukuran metode NASA-TLX adalah sebagai berikut [5]:

1. Memberi penjelasanmengenai indikator beban mental yang akan diukur kepada responden, yang dapat dilihat pada tabel 1 berikut:

Tabel 1.Indikator NASA TLX

\begin{tabular}{|c|c|c|}
\hline Skala & Rating & Keterangan \\
\hline $\begin{array}{l}\text { Kebutuhan } \\
\text { Mental } \\
(\mathrm{KM})\end{array}$ & Rendah, Tinggi & $\begin{array}{l}\text { Seberapa tinggi aktivitas mental dan persepsi yang dibutuhkan (berpikir, } \\
\text { memutuskan, menghitung, mengingat, memperhatikan, mencaridst). } \\
\text { Apakah tugas tersebut mudah atau sulit untuk dikerjakan, sederhana atau } \\
\text { kompleks, memerlukan ketelitian atau tidak }\end{array}$ \\
\hline $\begin{array}{l}\text { KebutuhanFi } \\
\text { sik } \\
(\mathrm{KF})\end{array}$ & Rendah, Tinggi & $\begin{array}{l}\text { Jumlah aktivitas fisiologis yang dibutuhkan (misalnya mendorong, } \\
\text { menarik, mengontrol putaran,dll) Apakah tugas itu mudah atau sulit untuk } \\
\text { dikerjakan, gerakan yang dibutuhkan cepat atau lambat, melelahkan atau } \\
\text { tidak }\end{array}$ \\
\hline $\begin{array}{l}\text { Kebutuhan } \\
\text { Waktu } \\
(\mathrm{KW})\end{array}$ & Rendah, Tinggi & $\begin{array}{l}\text { Jumlah tekanan yang berkaitan dengan waktu yang dirasakan selama } \\
\text { elemen pekerjaan berlangsung. Apakah pekerjaan perlahan atau santai } \\
\text { atau cepat dan melelahkan }\end{array}$ \\
\hline $\begin{array}{l}\text { Performansi( } \\
\mathrm{PF})\end{array}$ & $\begin{array}{l}\text { Tidaktepat, } \\
\text { sempurna }\end{array}$ & $\begin{array}{l}\text { Seberapa besar keberhasilan seseorang didalam pekerjaannya dan } \\
\text { seberapa puas dengan hasil kerjanya }\end{array}$ \\
\hline $\begin{array}{l}\text { Tingkat } \\
\text { Frustasi } \\
(\mathrm{TF})\end{array}$ & Rendah, Tinggi & $\begin{array}{l}\text { Seberapa tidak aman, putusasa, tersinggung, terganggu, dibandingkan } \\
\text { dengan perasaanaman, bersemangat, nyaman, dan kepuasandiri yang } \\
\text { dirasakan }\end{array}$ \\
\hline $\begin{array}{l}\text { Usaha } \\
\text { (U) }\end{array}$ & Rendah, Tinggi & $\begin{array}{l}\text { Seberapa keras kerja mental dan fisiologis yang dibutuhkan untuk } \\
\text { mencapai tingkat perfomansi saat ini }\end{array}$ \\
\hline
\end{tabular}

Sumber Hart dan Stavel and, 1981 dalam Diniaty \& Muliyadi, 2016 [9]

\section{Pemberian rating}

Responden diminta memberi rating terhadap keenam indicator beban mental. Range rating yang disediakan adalah 10100 dengan nilai 100 adalah rating tertinggi. Rating yang dipilih responden adalah subyektif tergantung pada beban mental yang dirasakan oleh responden tersebut.

\section{Pembobotan}

Responden diminta untuk memilih salah satu dari dua indikator yang dirasakan lebih dominan dan paling berpengaruh menimbulkan beban kerja mental terhadap pekerjaan tersebut. Kemudian jumlah indikator yang paling dominan tersebut dihitung dan jumlahnya dan menjadi bobot untuk tiap indikator beban mental. Tabel Pembobotan berpasangan dapat dilihat pada Tabel 2 sebagai berikut:
Tabel 2.Pembobotan Berpasangan

\begin{tabular}{|cll|cl|}
\hline No & Pasangan Pilihan & No & Pasangan Pilihan \\
\hline 1 & $\mathrm{KF} / \mathrm{KM}$ & 9 & $\mathrm{KM} / \mathrm{TF}$ \\
\hline 2 & $\mathrm{KF} / \mathrm{KW}$ & 10 & $\mathrm{KW} / \mathrm{PF}$ \\
\hline 3 & $\mathrm{KF} / \mathrm{PF}$ & 11 & $\mathrm{KW} / \mathrm{U}$ \\
\hline 4 & $\mathrm{KF} / \mathrm{U}$ & 12 & $\mathrm{KW} / \mathrm{TF}$ \\
\hline 5 & $\mathrm{KF} / \mathrm{TF}$ & 13 & $\mathrm{PF} / \mathrm{U}$ \\
\hline 6 & $\mathrm{KM} / \mathrm{KW}$ & 14 & $\mathrm{PF} / \mathrm{TF}$ \\
\hline 7 & $\mathrm{KM} / \mathrm{PF}$ & 15 & $\mathrm{U} / \mathrm{TF}$ \\
\hline 8 & $\mathrm{KM} / \mathrm{U}$ & & \\
\hline
\end{tabular}

Sumber: Hart dan Staveland, 1981 dalam

Diniaty \& Muliyadi, 2016

4. Menghitung nilai produk (Produk $=$ rating $\mathrm{x}$ bobot factor)

5. Menghitung Weighted Workload (WWL) dimana $W W L=\sum$ Produk

6. Menghitung rata-rata $\mathrm{WWL}$ Skor $=\sum$ Produk

7. Interpretasi Skor dengan merujuk pada table dibawah ini 
Tabel 3. Skor NASA TLX

\begin{tabular}{|cc|}
\hline Golongan Beban Kerja & Nilai \\
\hline Rendah & $0-9$ \\
\hline Sedang & $10-29$ \\
\hline Agak Tinggi & $30-49$ \\
\hline Tinggi & $50-79$ \\
\hline Sangat Tinggi & $80-100$ \\
\hline
\end{tabular}

Sumber: Hart dan Staveland, 1981 dalam

Diniaty\&Muliyadi, 2016

\subsection{Metode CVL}

Metode denyut nadi atau disebut juga dengan metode Cardiovascular Load (CVL) merupakannsalah satu metode tidak langsung yang dapat mengukur beban kerja fisiologis. Denyut nadi juga dipengaruhi oleh faktorfaktor lain, seperti stres, asupan makanan dan kondisi lingkungan [11]. Pengukuran denyut jantung dapat dilakukan dengan berbagai cara yaitu:

1.Merasakan denyut jantung yang ada pada arteri radial pada pergelangan tangan.

2.Mendengarkan denyut jantung dengan stethoscope [9]

Penggunaan nadi kerja memiliki beberapa keuntungan. Selain mudah, cepat, dan murah juga tidak memerlukan peralatan yang mahal, tidak menggangu aktivitas pekerja yang dilakukan pengukuran.Kepekaan denyut nadi akan segera berubah dengan perubahan pembebanan, baik yang berasal dari pembebanan mekanik, fisika, maupun kimiawi.

Denyut nadi untuk mengestimasi index beban kerja terdiri dari beberapa jenis [9] yaitu:

1. Denyut jantung pada saat istirahat (resting pulse) adalah rata-rata denyut jantung sebelum suatu pekerjaan dimulai.

2. Denyut jantung selama bekerja (working pulse) adalah rata-rata denyut jantung pada saat seseorang bekerja.

3. Denyut jantung selama istirahat total (recovery cost or recovery cost) adalah jumlah aljabar denyut jantung dan berhentinya denyut pada saat pekerjaan selesai dikerjakannya sampai dengan denyut berada pada kondisi istirahatnya.
4. Denyut kerja total adalah jumlah denyut jantung dari mulainya suatu pekerjaan sampai dengan denyut jantung istirahat

Lebih lanjut untuk menentukan klasifikasi beban kerja adalah dasarkan pada peningkatan denyut nadi maksimum karena beban kardiovaskulear (cardiovascular load $=\%$ CVL) [12]. Beban kardiovaskuler (cardiovasiculair $=\% \quad \mathrm{CVL})$ dihitung berdasarkan rumus dibawah ini [13]:

$$
\begin{aligned}
& \% \mathrm{CVL}= \frac{100(\text { Denyut nadi kerja-Denyut }}{\underline{\text { istirahat) Denyut maksimum-Denyut nadi }}} \\
& \text { istirahat }
\end{aligned}
$$

Di mana denyut nadi maskimum adalah (220umur) untuk laki-laki dan (200-umur) untuk wanita. Dari perhitungan \% CVL kemudian akan dibandingkan dengan klasifikasi yang telah ditetapkan sebagai berikut :

$$
\begin{array}{ll}
30-<60 \% & =\text { Diperlukan perbaikan } \\
60-<80 & =\text { Kerja dalam waktu singkat } \\
80-<100 \% & =\text { Diperlukan tindakan segera } \\
>100 \%=\text { Tidakdiperbolehkan beraktivitas }
\end{array}
$$

\subsection{Energy Expenditure}

Energy expenditure atau besarnya energi yang di keluarkan untuk suatu pekerjaan dapat di ukur dengan memperhitungkan denyut jantung dan faktor demografi. Kamalakama et al., 2007 menyatakan model persamaan untuk menghitung beban kerja dengan rumus berikut [14]:

$E$ cost $=-1967+8,58 H R+25,1 H T+4,5 A-7,4 R H R+67,8 G$

Dengan,

Ecost : Beban kerja (watt)

HR : Denyutjantung saat bekerja

HT : Tinggi badan (inci)

A : Umur (tahun)

RHR : Denyut jantung saat beristirahat

$\mathrm{G} \quad$ : Jenis kelamin $(\mathrm{m}=0, \mathrm{f}=1)$

1 watt setara dengan $0,0143 \mathrm{kkal} /$ menit

Hasil dari perhitungan energy ekspenditur kemudian dibandingkan dengan table berikut 
Tabel 4. Klasifikasi Energy Expenditur

\begin{tabular}{|c|c|c|c|}
\hline \multirow[t]{2}{*}{$\begin{array}{l}\text { Klasifikasi } \\
\text { Pekerjaan }\end{array}$} & \multicolumn{2}{|c|}{$\begin{array}{l}\text { Total Energy } \\
\text { Ekspenditure }\end{array}$} & \multirow{2}{*}{$\begin{array}{l}\text { Denyut } \\
\text { Jantung } \\
\text { (denyut } \\
\text { /menit) }\end{array}$} \\
\hline & $\begin{array}{l}\text { Kjoule } \\
\text { /menit) }\end{array}$ & $\begin{array}{c}\text { Kkal } \\
\text { /menit }\end{array}$ & \\
\hline Ringan & $\operatorname{Max} 10$ & $\operatorname{Max} 2,5$ & $\leq 90$ \\
\hline Sedang & $\operatorname{Max} 20$ & $\operatorname{Max} 5$ & $90-100$ \\
\hline Berat & $\operatorname{Max} 30$ & $\operatorname{Max} 7,5$ & $100-120$ \\
\hline Sangat & $\operatorname{Max} 40$ & $\operatorname{Max} 10$ & $120-140$ \\
\hline Berat & & & \\
\hline $\begin{array}{l}\text { Ekstream } \\
\text { Berat }\end{array}$ & $\operatorname{Max} 50$ & $\operatorname{Max} 12,5$ & $140-160$ \\
\hline
\end{tabular}

Sumber: Kroemer et al dalamIridiastadi et al, 2014[14]

\section{Hasil dan Pembahasan}

\subsection{Pengukuran Beban Psikologis}

Pada pengukuran beban psikologis, pengukuran menggunakan metode NASA_TLX. Responden yang dipilih adalah kuli panggul berjenis kelamin laki-laki dengan pengalaman bekerjan menjadi kuli panggul lebih dari 2 tahun.

Responden diberikan penjelasan mengenai masing-masing indicator pengukuran beban mental. Kemudian diminta untuk mengisi kuisioner NASA-TLX tersebut secara subjektif sesuai dengan apa yang dirasakan responden.

\section{Pemberian Peringkat (Rating Scale)}

Pada tahap ini reponden akan diminta untuk memberi skor dengan rentang 10-100 terhadap masing-masing indikator, seperti Tabel 5.berikut :

Tabel 5. Rating ScaleNASA-TLX

\begin{tabular}{|lll|}
\hline Responden & \multicolumn{1}{c}{$\begin{array}{c}\text { Aspek Beban } \\
\text { Kerja }\end{array}$} & Skor \\
\hline Mat Alim & KebutuhanMental (KM) & 80 \\
(49 tahun) & KebutuhanFisik (KF) & 75 \\
& Kebutuhan Waktu (KW) & 80 \\
& Usaha (U) & 85 \\
& Performa (PF) & 90 \\
& Tingkat Frustasi (TK) & 30 \\
\hline Alam & KebutuhanMental (KM) & 85 \\
(39tahun) & KebutuhanFisik (KF) & 90 \\
& Kebutuhan Waktu (KW) & 80 \\
& Usaha (U) & 95 \\
& Performa (PF) & 75 \\
\hline
\end{tabular}

\begin{tabular}{|llc|}
\hline & Tingkat Frustasi (TK) & 10 \\
\hline Responden & \multicolumn{1}{c|}{$\begin{array}{c}\text { Aspek Beban } \\
\text { Kerja }\end{array}$} & Skor \\
& \multicolumn{1}{c|}{ KebutuhanMental (KM) } & 75 \\
Sdidin & KebutuhanFisik (KF) & 90 \\
(39 tahun) & Kebutuhan Waktu (KW) & 85 \\
& Usaha (U) & 90 \\
& Performa (PF) & 70 \\
& Tingkat Frustasi (TK) & 40 \\
\hline
\end{tabular}

Bisa dilihat dari table diatas dapat dihitung rata-rata skor beban kerja yang memiliki nilai diatas 80 dari ketiga responden yaitu pada Kebutuhan Mental (KM) dengan skor rata-rata 80, Kebutuhan Fisik (KF) dengan skor ratarata 85, Kebutuhan Waktu (KW) dengan skor rata-rata 81,6 dan Usaha (U) dengan skor ratarata 90 yang artinya beban kerja aspek-aspek tersebut sangat tinggi.

\section{Pembobotan}

Responden memilih diantara dua indikator yang paling dominan dengan hasil sebagai berikut

Tabel 6.Pembobotan Berpasangan

\begin{tabular}{|c|l|c|c|c|}
\hline No & Pasangan & $\begin{array}{c}\text { Mat } \\
\text { Alim }\end{array}$ & Alam & AdidinSlamet \\
\hline 1 & $\mathrm{KF} / \mathrm{KM}$ & $\mathrm{KM}$ & $\mathrm{KF}$ & $\mathrm{KF}$ \\
2 & $\mathrm{KF} / \mathrm{KW}$ & $\mathrm{KW}$ & $\mathrm{KF}$ & $\mathrm{KF}$ \\
3 & $\mathrm{KF} / \mathrm{PF}$ & $\mathrm{PF}$ & $\mathrm{KF}$ & $\mathrm{KF}$ \\
4 & $\mathrm{KF} / \mathrm{U}$ & $\mathrm{U}$ & $\mathrm{U}$ & $\mathrm{KF}$ \\
5 & $\mathrm{KF} / \mathrm{TF}$ & $\mathrm{KF}$ & $\mathrm{KF}$ & $\mathrm{KF}$ \\
6 & $\mathrm{KM} / \mathrm{KW}$ & $\mathrm{KM}$ & $\mathrm{KM}$ & $\mathrm{KW}$ \\
7 & $\mathrm{KM} / \mathrm{PF}$ & $\mathrm{PF}$ & $\mathrm{KM}$ & $\mathrm{KM}$ \\
8 & $\mathrm{KM} / \mathrm{U}$ & $\mathrm{U}$ & $\mathrm{U}$ & $\mathrm{U}$ \\
9 & $\mathrm{KM} / \mathrm{TF}$ & $\mathrm{KM}$ & $\mathrm{KM}$ & $\mathrm{KM}$ \\
10 & $\mathrm{KW} / \mathrm{PF}$ & $\mathrm{PF}$ & $\mathrm{KW}$ & $\mathrm{KW}$ \\
11 & $\mathrm{KW} / \mathrm{U}$ & $\mathrm{U}$ & $\mathrm{U}$ & $\mathrm{U}$ \\
12 & $\mathrm{KW} / \mathrm{TF}$ & $\mathrm{KW}$ & $\mathrm{KW}$ & $\mathrm{KW}$ \\
13 & $\mathrm{PF} / \mathrm{U}$ & $\mathrm{PF}$ & $\mathrm{U}$ & $\mathrm{U}$ \\
14 & $\mathrm{PF} / \mathrm{TF}$ & $\mathrm{PF}$ & $\mathrm{PF}$ & $\mathrm{PF}$ \\
15 & $\mathrm{U} / \mathrm{TF}$ & $\mathrm{U}$ & $\mathrm{U}$ & $\mathrm{U}$ \\
\hline
\end{tabular}

Dari pembobotan diatas terlihat hasil indicator terbanyak yaitu KF (Kebutuhan Fisik), KM (Kebutuhan Mental), KW (Kebutuhan Waktu) dan U (Usaha).

\section{Menghitung Nilai Produk}

Pada tahap ini, kami akan menghitung nilai produk dengan cara mengkalikan 
jumlah bobot dengan skor rating dengan hasil berikut :

Tabel 7. Nilai Produk

\begin{tabular}{|c|c|c|c|c|}
\hline Responden & Aspek & Skorrat & tJumlah & Hasil \\
\hline & Beban & ing & Bobot & \\
\hline & Kerja & & & \\
\hline Mat Alim & KM & 80 & 3 & 240 \\
\hline (49 tahun) & $\mathrm{KF}$ & 75 & 1 & 75 \\
\hline & KW & 80 & 2 & 160 \\
\hline & $\mathrm{U}$ & 85 & 4 & 340 \\
\hline & $\mathrm{PF}$ & 90 & 5 & 450 \\
\hline & $\mathrm{TF}$ & 30 & 0 & 0 \\
\hline Nilai Produk & & $: 1265$ & & \\
\hline Alam & KM & 85 & 3 & 255 \\
\hline$(39$ & $\mathrm{KF}$ & 90 & 4 & 360 \\
\hline tahun) & KW & 80 & 2 & 160 \\
\hline & $\mathrm{U}$ & 95 & 5 & 475 \\
\hline & PF & 75 & 1 & 75 \\
\hline & TF & 10 & 0 & 0 \\
\hline Nilai Produk & & $: 1325$ & & \\
\hline Responden & Aspek & Skor & Jumlah & Hasil \\
\hline & Beban & rating & Bobot & \\
\hline & Kerja & & & \\
\hline Adidin & KM & 75 & 2 & 150 \\
\hline Slamet & $\mathrm{KF}$ & 90 & 5 & 450 \\
\hline (39 tahun) & $\mathrm{KW}$ & 85 & 3 & 255 \\
\hline & $\mathrm{U}$ & 90 & 4 & 360 \\
\hline & $\mathrm{PF}$ & 70 & 1 & 70 \\
\hline & $\mathrm{TF}$ & 40 & 0 & 0 \\
\hline Nilai Produk & : 1285 & & & \\
\hline
\end{tabular}

Jumlah nilai produk diatas kemudian akan dibagi 15 yaitu jumlah pembobotan berpasangan yang hasilnya disebut rata-rata Weighted Workload (WWL)

\section{Weighted Workload (WWL)}

Nilai Produk adalah sama dengan Weighted Workload (WWL). Berikut ini adalah hasil dari perhitungan rata-rata Weighted Workload (WWL) dari ketiga responden :

Tabel 8. Rata-rata Weighted Workload

\begin{tabular}{|lcc|}
\hline Responden & WWL & $\begin{array}{c}\text { Rata-Rata } \\
\text { WWL }\end{array}$ \\
\hline $\begin{array}{l}\text { Mat Alim } \\
\text { (49 tahun) }\end{array}$ & 1265 & 84,33 \\
\hline $\begin{array}{l}\text { Alam } \\
\text { (39 tahun) }\end{array}$ & 1325 & 88,33 \\
\hline Adidin Slamet & 1285 & 85,66 \\
\hline
\end{tabular}

(39 tahun)

5. Interpretasi Skor NASA-TLX

Hasil dari nilai skor kemudian dibandingkan dengan table skor NASA-TLX dengan penggolongan beban kerja yang dapat dilihat pada table 9. Berikut ini:

Tabel 9. Penggolongan Beban Kerja

\begin{tabular}{|lccc|}
\hline Responden & $\begin{array}{l}\text { Skor } \\
\text { NASA } \\
\text {-TLX }\end{array}$ & $\begin{array}{c}\text { Kategori } \\
\text { Nilai }\end{array}$ & $\begin{array}{c}\text { Golongan } \\
\text { Beban } \\
\text { Kerja }\end{array}$ \\
\hline $\begin{array}{l}\text { Mat Alim } \\
\text { (49 tahun) }\end{array}$ & 84,33 & $80-100$ & $\begin{array}{l}\text { Sangat } \\
\text { Tinggi }\end{array}$ \\
\hline $\begin{array}{l}\text { Alam } \\
\text { (39 tahun) }\end{array}$ & 88,33 & $80-100$ & $\begin{array}{l}\text { Sangat } \\
\text { Tinggi }\end{array}$ \\
\hline $\begin{array}{l}\text { Adidin } \\
\text { Slamet } \\
\text { (39tahun) }\end{array}$ & 85,66 & $80-100$ & Sangat \\
Tinggi
\end{tabular}

Hasil dari interpretasi skor NASA-TLX diketahui bahwa ketiga responden memiliki beban kerja mental sangat tinggi dengan ratarata skor yaitu 86,10

\subsection{Perhitungan Beban Fisiologis}

Beban fisiologis atau beban fisik dihitung dengan metode denyut nadi atau \% CVL. Ketiga respon den berjenis kelamin laki-laki.. Pengukuran dilakukan sebanyak 2 kali. Pengukuran pertama diambil pada kondisi istirahat (restingpulse) yaitu denyut jantung sebelum suatu pekerjaan dimulai. Pengukuran kedua diambil selama bekerja (working pulse) yaitu denyut jantung pada saat seseorang bekerja. Hasil pengukuran \% CVL bias dilihat pada table 10. Berikut ini: 
Tabel 10. Klasifikasi \%CVL

\begin{tabular}{|c|c|c|c|c|c|c|}
\hline \multirow[b]{2}{*}{ Nama } & \multirow[b]{2}{*}{ Usia } & \multicolumn{3}{|c|}{ Denyut Jantung } & \multirow{2}{*}{$\begin{array}{l}\% \\
\text { CVL }\end{array}$} & \multirow{2}{*}{$\begin{array}{l}\text { Klasifi } \\
\text { kasi }\end{array}$} \\
\hline & & \begin{tabular}{|l} 
Istirah \\
at
\end{tabular} & Bekerja & Maks & & \\
\hline $\begin{array}{l}\text { Mat } \\
\text { alim }\end{array}$ & 49 & 63 & 140 & 171 & 71,29 & $\begin{array}{l}\text { Kerja } \\
\text { dalam } \\
\text { waktu } \\
\text { singkat }\end{array}$ \\
\hline Alam & 39 & 68 & 140 & 181 & 63,71 & $\begin{array}{l}\text { Kerja } \\
\text { dalam } \\
\text { waktu } \\
\text { singkat }\end{array}$ \\
\hline $\begin{array}{l}\text { Adidin } \\
\text { selamet }\end{array}$ & 39 & 64 & 140 & 181 & 64,95 & $\begin{array}{l}\text { Kerja } \\
\text { dalam } \\
\text { waktu } \\
\text { singkat }\end{array}$ \\
\hline
\end{tabular}

Hasil dari klasifikasi \%CVL diketahui bahwa berdasarkan denyut jantung, ketiga pekerja masuk klasifikasi bekerja dalam waktu singkat. Perhitungan selanjutnya yaitu menghitung energi ekspenditur menggunakan rumus

$$
E_{\text {cost }}=-1967+8,58 H R+25,1 H T+4,5 A-7,4 R H R+67,8 G
$$

Hasil perhitungan dan pengklasifikasian beban kerja dapat dilihat pada table 11. Berikut ini:

Tabel 11. Perhitungan Energi Ekspenditur

\begin{tabular}{|c|c|c|c|c|c|c|}
\hline \multirow[b]{2}{*}{ Nama } & \multirow[b]{2}{*}{ Umur } & \multirow{2}{*}{$\begin{array}{l}\text { Tinggi } \\
\text { badan } \\
\text { (inchi) }\end{array}$} & \multicolumn{2}{|c|}{\begin{tabular}{|c|} 
DenyutJant \\
ung
\end{tabular}} & \multirow{2}{*}{$\begin{array}{c}\text { Total } \\
\text { Energi( } \\
\text { kkal/m } \\
\text { nt) }\end{array}$} & \multirow[b]{2}{*}{$\begin{array}{l}\text { Kate } \\
\text { gori }\end{array}$} \\
\hline & & & $\begin{array}{l}\text { Istirah } \\
\text { at }\end{array}$ & $\begin{array}{l}\text { Bekerj } \\
\text { a }\end{array}$ & & \\
\hline $\begin{array}{l}\text { Mat } \\
\text { Alim }\end{array}$ & 49 & 62 & 63 & 140 & 7,10 & Berat \\
\hline Alam & 39 & 63 & 68 & 140 & 7,61 & Berat \\
\hline $\begin{array}{l}\text { Adidin } \\
\text { selamet }\end{array}$ & 39 & 60 & 64 & 140 & 6,32 & Berat \\
\hline
\end{tabular}

Perhitungan energy ekspenditur ini dipengaruhi oleh usia, tinggi badan dan denyut jantung. Penambahan metode perhitungan energi ekspenditur ini melengkapi kekurangan metode \%CVL dimana dari perhitungan \%CVL ketiga pekerja masuk klasifikasi bekerja dalam waktu singkat namun tidak diketahui termasuk klasifikasi beban kerja ringan, sedang, berat, sangat berat atau ektrem berat.

Pengukuran beban fisiologis dengan \%CVL dan perhitungan total energy ekspenditur ini mendapatkan hasil yang lebih baik dan valid dibandingkan hanya menggunakan metode \%CVL saja seperti pada penelitian sebelumnya. Hal ini dikarenakan selain mengetahui klasifikasi pekerjaan berdasarkan denyut jantung, juga dapat mengetahui konsumsi total energy per menit (KKal/menit) yang dibutuhkan oleh pekerja kuli panggul. Hasil dari perhitungan total energi (Kkal) yang dikeluarkan per menit dari ketiga responden, diketahui bahwa pekerjaan kuli panggul ini termasuk pekerjaan kategori berat.

\section{Kesimpulan dan Saran}

Berdasarkan pengukuran beban psikologis dengan menggunakan kuisioner NASA-TLX yang di isi respon den secara subjektif diketahui bahwa beban kerja mental rata-rata yang diterima responden yaitu kuli panggul tergolong mental sangat tinggi dengan rata-rata skor yaitu 86,10. Dengan perhitungan indicator tertinggi yaitu Kebutuhan Fisik (KF) seperti menarik, mendorong dan mengangkat barang dengan beban berat, Kebutuhan Mental (KM) seperti menghitung dan mengingat jumlah barang yang dibongkar, Kebutuhan Waktu (KW) kuli angkut dituntut untuk bekerja secara cepat dan melelahkan dan usaha (U) baik dari fisik dan mental untuk menyelesaikan pekerjaan bongkar muat barang tersebut.

Sedangkan untuk beban kerja fisiologis yang dialami pekerja kuli panggul berdasarkan perhitungan \% CVL dan perhitungan total energi adalah pekerjaan yang dilakukan dalam waktu singkat dan tergolong pekerjaan berat. Bekerja pada kondisi seperti ini, sangat beresiko menyebabkan kelelahan fisik dan mental apabila dilakukan secara terus menerus dan dalam waktu yang lama. Kondisi kelelahan ini apabila diabaikanakan beresiko terjadinya penurunan performa kerja, cedera, kecelakaan, maupun penyakit akibat kerja. Untuk itu diharapkan PT. PELINDO III dapat 
memperbaiki sistem kerja dan memperbaiki kebijakannya baik dari system upah maupun metode kerja seperti penyediaan alat bantu angkat beban atau alat bantu panggul agar dapat menurunkan beban kerja ke dalam kategori aman.

Saran untuk penelitian selanjutnya adalah selain mengukur beban psikologis dan beban fisiologis juga sebaiknya mengukur berapa lama pekerja seharusnya beristirahat sehingga pekerja mendapatkan waktu istirahat yang cukup untuk dapat memulihkan energy setelah bekerja khususnya pekerjaan berat.

\section{Daftar Pustaka}

[1] S. Ahmed, S, "Fatigue Differences Between Asian and Western Population in Prolonged Mentally Demanding WorkTasks", International Journal of Industrial Ergonomics 54, pp.103-112, Jul. 2016.

[2] D.Afshariet al, "The Effect of Heat Exposure on Physical Workload and Maximum Acceptable Work Duration (MAWD) in A Hot and Dry Climate", Urban Climate 27, pp 142-148, 2019.

[3] Novianti, "Pengaruh Imbal Jasa Dan Beban Kerja Terhadap Prestasi Kerja Karyawan Pt Agape Pratama Indonesia", Jemasi. Vol.14 No.2, Jul-Des. 2018.

[4] M. Fallahi et al. "Effect of Mental Workload on Physiological And Subjective Responses During Traffic Density Monitoring",Applied Ergonomics. Vol.52, pp. 95-103, 2016.

[5] D. Purwaningsih et al, "Analisis Beban Kerja Fisik dan Mental PT.Energi Agro Nusantara Dengan Metode Cardiovascular Load (CVL) \& NASA-TLX" in Seminar Nasional Teknik

Industri 2017, Universitas Pembangunan Nasional "Veteran" Jawa Timur, 2017. pp. 133-140

[6] E. Darvishi, M. Meimanatabadi, "The Rate of Subjective Mental Workload and its Correlation with Musculoskeletal
Disorders in Bank Staff in Kurdistan. Iran' in 6th International Conference on Applied Human Factors and Ergonomics and the Affiliated Conferences, AHFE, Procedia Manufacturing 3, 2015. Pp. 3742.

[7] P. Fithri, W. F. Anisa, "Pengukuran Beban Kerja Psikologis dan Fisiologis Pekerja di Industri Tekstil', JurnalOptimasiSistemIndustri. Vol.16 No.2, pp. 120-130, 2017.

[8] B. Chancard et al., "Analisis Beban Kerja Karyawan dengan Menggnakan Metode SWAT dan NASA TLX", Jurnal MATRIK, Vol. XX No. 1., pp. 13-24, September. 2019.

[9] M. Mutia et al.,"Pengukuran Beban Kerja Fisiologis dan Psikologis pada Operator Pemetik Teh dan Operator Produksi TehHijau di PT Mitra Kerinci",Jurnal Optimasi Sistem Industri. Vol. 13 No. 1, pp. 503-517, April. 2014.

[10] D. Diniaty dan Z. Muliyadi, "Analisis Beban Kerja Fisik Dan Mental Karyawan. Pada Lantai Produksi di PT. Pesona Laut Kuning", Jurnal Sains, Teknologi dan Industri, pp. 203-210, 2016.

[11] L. Yang et al., "Evaluation of Physiological Workload Assessment Methods Using Heart Rate and Accelerometry For a Smart Wearable System", Ergonomics. Informa UK Limited, Feb. 2019.

[12] I. Siregar et al., "Analysis of Physiological Workload Approach in Packing Stations to Determine Optimal Workload" in 2nd Nommensen International Conference on Technology and Engineering, IOP Conf. Series: Materials Science and Engineering 420, 2018. 01202

[13] S. Borah, "Physiological workload of hill farm women of Meghalaya, Indiainvolved infirewoodcollection" in 6th International Conference on Applied Human Factors and Ergonomics (AHFE 2015) and the Affiliated 
Conferences, Procedia Manufacturing 3, 2015. pp. 4984-4990.

[14] H.Iridiastadiet

al,

"FisiologiKerja/KapasitasKerjaFisik",Erg onomi Suatu Pengantarl, Pertama. Bandung, Penerbit:PT. Remaja Rosda karya Offset, 2014, Bab 4, Sub.Bab D, pp. 108-121 